\title{
Vulnerability of Agricultural Production in the Brazilian Semi-Arid: An Empirical Approach including Risk
}

\author{
Minella Alves Martins ${ }^{1}$, Stefan Hochrainer-Stigler ${ }^{2}$, Georg Pflug ${ }^{2}$ \\ Received: 27/01/2016 / Accepted: 10/03/2017 / Published online: 01/06/2017
}

\begin{abstract}
Agricultural production risk is getting increasing attention in the science and the policy domain due to its strong connection with food security and its potential to trigger systemic risks. Particularly in semi-arid regions, weather and environmental conditions can seriously affect agricultural production. Brazil stands out exceptionally as it has one of the most populated semi-arid areas globally. Nevertheless, risk assessment of crop production for these regions is lacking, but essentially needed for policy and risk management purposes. To fill part of this gap, this paper provides first estimates of crop yield risk for the semi-arid in Brazil on the municipality level from an empirical perspective. It was found that many highly vulnerable municipalities are located in states such as Ceará, Piauí, Pernambuco, and Paraíba. These hotspot regions may be prioritized in terms of public investments in order to help them decrease current and future vulnerability related to crop production. Especially climate change impacts may worsen the situation considerably in the future and should be included already in current adaptation strategies.
\end{abstract}

Key words Drought; Maize; Bean; Subsistence agriculture; Rainfed production; Risk.

\section{INTRODUCTION}

Agricultural production risk is getting increasing attention in the science and the policy domain due to its strong connectance with food security and its potential to trigger systemic risks. For example, extreme weather events can destabilize markets and have the potential to trigger local or regional food crises. This can result in humanitarian crisis, national or regional instabilities as well can lead to mass migration. Recent examples include the 2010 Pakistan flood events which led to a sharp decrease in rural incomes and a large increase in food insecurity as well as the 2011 drought event in East Africa, which affected more than 13 million people. While already today global crop production lags behind growth demand (World Economic Forum 2017) the situation will likely worsen in the future due to population growth and climate change. For example there is an expected increase in demand of 60 percent by 2050 due to rising population and growth of the middle class (Alexandratos and Bruinsma 2012). Additionally, climate change impacts on yield can be expected to worsen not only in poor and food-insecure countries but also the key exporting breadbasket regions including North and South America (WRI 2013).

\footnotetext{
${ }^{1}$ Earth System Science Center, National Institute for Space Research (CCST/INPE), Brazil.

${ }^{2}$ Risk and Resilience Program, International Institute for Applied Systems Analysis (IIASA), Austria.

*Corresponding author: E-mail address: minella.martins@inpe.br
} 
Particularly in semi-arid regions, weather and environmental conditions can seriously affect agricultural production. Such regions are generally characterized by low levels of rainfall and high levels of evapotranspiration, affecting water supply for crops, livestock as well as human consumption. Of the total land area around the world, total semi-arid zones are about 15 percent (United Nation 2015a). In Latin America, similarly to Africa and Asia, 15-25 percent of the population lives in semi-arid areas, mostly in small isolated rural communities (Ella 2011). Brazil stands out exceptionally here as it has one of the most populated semi-arid areas globally, e.g. more than 22 million people living there with almost 40 percent in rural areas (Ibge 2012) which depend mostly on rainfed agriculture for their subsistence. Worryingly, rainfed agriculture in the Semi-Arid of Brazil (SAB) has been frequently affected by adverse weather conditions in the past which caused high stress on farmers and the rural population in general. According to Marengo (2008) during 100 years, on average 18 to 20 drought years can be expected and the twentieth century was one of the driest years ever, registering 27 drought years in total. Most severe drought events resulted in heavy crop failure and high food insecurity in those rural areas; according to official statistics (Ibge 2013) SAB shows the most critical conditions of the country in terms of food security, and 38 percent of the population experienced restrictions in dietary needs.

In this context, agriculture production in semi-arid areas is of high relevance from a social point of view, especially for family farming, which is an important segment within the agriculture sector in Brazil. The definition by the Brazilian Family Farming Act (Law n. 11.326) is that it is an agricultural producer which is directly responsible for farm management, using mainly family labor and earn a substantial part of the total family's income from agricultural activities (Lindoso et al. 2014). About 89 percent of farms in the SAB are family farms (Banco do Nordeste 2010) and this segment is the one which is most affected by drought events, partly because of their few resources for adaptation. Special focus on these areas is therefore given by the Brazilian Government as well as civil society (Brazilian Government 2013; Fonseca et al. 2014). Nevertheless, current estimates of crop production are focusing on average yields and do not provide risk based estimates on the municipality level. As IPCC ( 2012) pointed out, there is an urgent need to provide estimates of the likelihood of extreme events and its consequences. Furthermore, the need for such estimates is also prominently featured in the Sustainable Development Goals which recommends setting up and developing baseline estimates where they do not exist yet to monitor progress and to address gaps in current data collection (see, SDG, point 57) (UN 2015b). This can also be related to the Sendai Framework for Disaster Risk Reduction (UNISDR 2015) which emphasizes the need to collect and share data for monitoring and the continuous evaluation of adopted disaster risk reduction strategies.

The analysis in this paper should fill part of this gap by providing first estimates of crop yield risk for the $\mathrm{SAB}$ in Brazil on the municipality level from an empirical perspective. Special attention is given on the most critical factors for crop vulnerability which is defined here in accordance to the IPCC (2012) definition of vulnerability as the propensity and predisposition to be adversely affected. This should support the Brazilian government in identifying appropriate policies, including investments in mitigation options and emergency relief actions, to help communities to recover from and prepare against drought events. In doing so, three different "perspectives" on crop risk are introduced and seen as relevant for various decision makers within the region. The first perspective focuses on the range of possible crop yields, the second perspective emphasizes on minimum crop yields while the third perspective centers on risk of crop yields and includes a stress threshold representing crop resistance (as crops are usually tolerant to a certain level of water deficit). The introduced perspectives should be beneficial for stakeholders and policy makers to help them to prioritize emergency and preparedness actions on the most vulnerable municipalities in the SAB.

The paper is organized as follows. Section 2 provides background information of the case study in Brazil (Section 3) and current drought adaptation options applied. Afterwards, Section 4 presents the methodology employed, while Section 5 presents the corresponding results. Finally, Section 6 discusses the results in a broader context and ends with a conclusion and outlook to the future. 


\section{DROUGHT ADAPTATION IN BRAZIL}

As already indicated, one of the most vulnerable regions in Brazil are rural semi-arid areas (Simões et al. 2010). Agriculture potential in the Semi-Arid in Brazil (SAB) is strongly limited due to generally insufficient rainfall (Krol and Bronstert 2007). Indeed, the most severe droughts since the beginning of colonization in the sixteenth century happened in SAB, they are quite common and affecting mainly family farming and food supply (Marengo et al. 2016). Especially for those families who depend on agriculture for their subsistence, the reduced harvest usually results in a substantial reduction of food supplies available during the next year. Similarly, the loss of crops not only generate debt (e.g. to buy new seeds), but also means that households cannot make any debt repayments already outstanding (Morisson 2010), eventually leading to vicious poverty cycles.

While it is true that meteorological droughts are one of the natural disaster types which cannot be prevented, one nevertheless can adapt to it. Actions towards adaptation have increased in its importance and are now in the center of the international agenda along with climate mitigation (Lindoso et al. 2014). For example, adaptation is one of the main focus areas of the IPCC's Fifth Assessment Report (AR5) which suggests adaption and mitigation actions given climate change projections should be identified for several parts of the world (Magrin et al. 2014). For SAB, AR5 restates that droughts will intensify along the $21^{\text {st }}$ century in some seasons and areas due to reduced precipitation and/or increased evapotranspiration and these effects could affect crop yields, local economies and food security (Magrin et al. 2014). Additionally, some researchers on AR5 suggest that water scarcity for agriculture will also have important social impacts such as potential full-scale migrations in the SAB (Krol and Bronstert 2007; Krol et al. 2006). As future adaptive practices, genetic advances, suitable soil and technological management strategies are suggested to induce an increase in some crops' yield despite unfavorable future climate conditions (Magrin et al. 2014). The current situation in the SAB is however connected to large weather variabilities, water deficiency, low adaptation capacity and poverty. Hence, the Brazilian government has implemented some adaptation policies and emergency relief actions to help communities to recover after and prepare for drought events (Figure 1).

Such operations can be quite costly. For example, during the last drought year in 2012/2013 total expenditures for emergency operations were about US\$ 5 billion. This included assistance to insurance companies, giving emergency loans, providing assistance in well drillings and general recovery measures (Brazilian Government 2013). Additional adaptive practices are developed by the Brazilian Agricultural Research Corporation (Embrapa), a state-owned company in Brazil. They provide assistance to improve agronomic practices, as well as indicate the infeasible locations and seasons for different crops, e.g. through agricultural risk zoning. However, not only the government is taking adaptation actions, civil society organizations as well have formed a coalition known as the ASA (Articulação do Semiárido Brasileiro) which implemented since 1999 the "Programme for One Million Cisterns". The goal is to build one million of cement cisterns for storage of rainwater collected through gutters attached to roofs of houses (Fonseca et al. 2014). Even though many adaptive practices have been applied in the SAB recently, they were not enough to avoid losses in the agriculture sector, which is an indication that a more targeted planning could be beneficial to enhance adaptive capacity and, consequently, decrease vulnerability. As discussed, identifying some key dimension of vulnerability of crop production as well as risk of experiencing low crop yields on a more detailed spatial scale for SAB may be a crucial step towards the goal of a more targeted planning of current and future investments in adaptation options. 


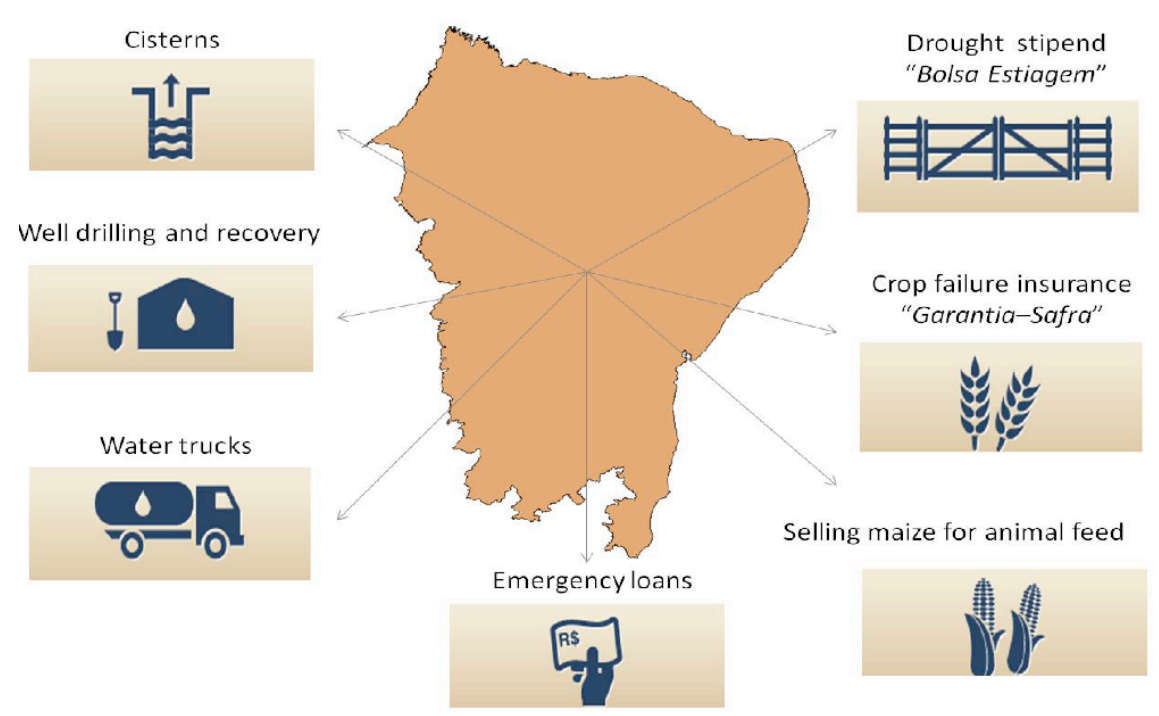

Figure 1. Adaptation policies and Emergency relief action in SAB. Courtesy: Nobre 2014.Source: Brazil 2013.

\section{CASE STUDY AREA}

The selected case study area, namely the SAB region is in the Northeast of Brazil (see Figure 2). It is the second most populated region in Brazil and its climate is classified as Bsh climate according to the Koppen classification, i.e. a hot semi-arid climate. The region coincides with the poorest regions in Brazil presenting on average 40 percent of the population living below the poverty line and also has the worst social and economic indices, e.g. the Human Development Index is around 0.59, about 50 percent of the total population has no income or depends on government benefits and about 30 percent earns up to only US\$400 per month (Ibge 2012).

Climate wise, crop vulnerability in the SAB has a strong climate component, e.g. weather and climatic variables are very important for crop production. The weather in SAB is characterized by annual average rainfall up to $800 \mathrm{~mm}$, solar average radiation of $2800 \mathrm{~h} /$ year, average temperature between $23^{\circ}$ to $27^{\circ} \mathrm{C}$, evaporation of $2000 \mathrm{~mm} /$ year and relative humidity about $50 \%$ (Moura et al. 2007). However, the distribution of rainfall over the year and its temporal and spatial variability increase the risk of crop losses for rainfed agriculture due to dry spells. Furthermore, weather variability is seen as one of the main threats to crop production in this region and is influenced by geographical position, topography, surface characteristics and meteorological systems (Marengo et al. 2011). Other determinants to climatic variability on annual and interannual scales are the El Niño-Southern Oscillation - ENSO and Tropical Atlantic Dipole. Both phenomena's are caused by oscillation of Sea Surface Temperature (SST) in the equatorial Pacific and tropical Atlantic, respectively. The warm ENSO phase, called El Niño and the positive Dipole cause droughts in SAB due to change on the atmospheric circulation pattern (Moura and Shukla 1981; Ropelewski and Halpert 1989; Serra 1941). Some research already tried to link such phenomenon with crop production and found some relationship for SAB (Martins 2012; Silva et al. 2002; Berlato et al. 2005). Unsurprisingly, due to the recurrent droughts in SAB agriculture is not composed by miscellaneous crops. The most important cultivated crops in this region are maize and bean which is therefore also the main crops looked at in this article. Both crops are used as staple food for the population as well as silage to feed animals and as green manure and for soil protection. As will be seen, due to recurrent droughts, maize and bean show large differences in productivity on an inter-annual scale, 
including a complete failure during severe droughts. The average productivity in the semi-arid region of Brazil is around $650 \mathrm{~kg} / \mathrm{ha}$ for Maize and $342 \mathrm{~kg} / \mathrm{ha}$ for Bean (in 2014), which is well below the national average of $5100 \mathrm{~kg} / \mathrm{ha}$ (maize) and $832 \mathrm{Kg} /$ ha (bean) (Ibge 2015).

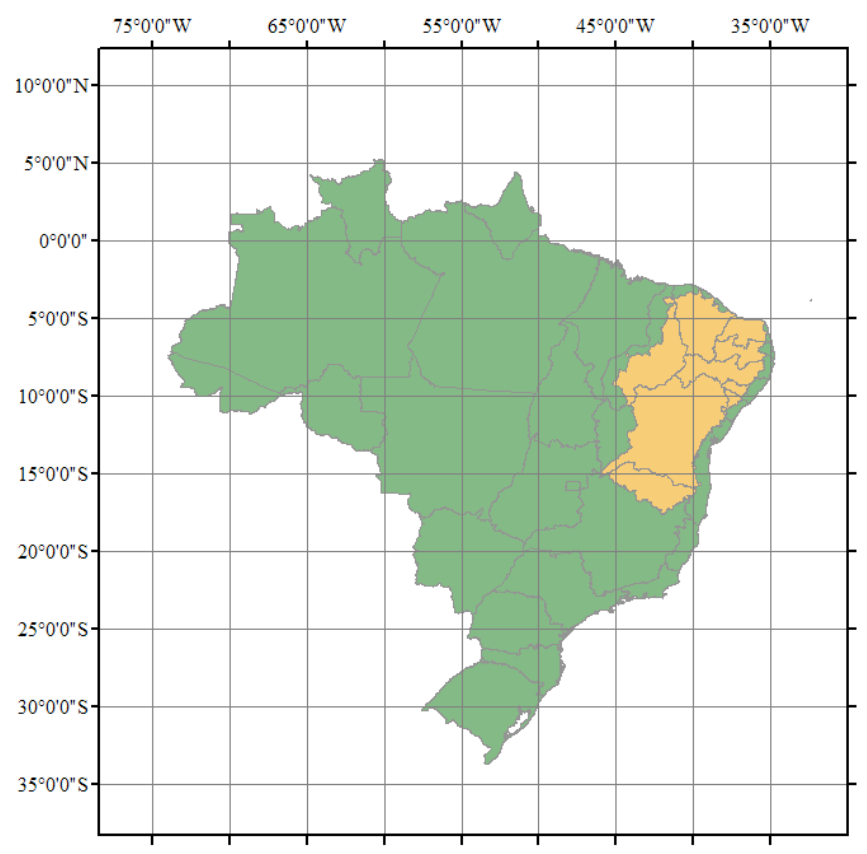

Figure 2. Case study area: Brazilian semi-arid (yellow shaded).

It should be noted that although rainfed agriculture in the semi-arid has low economic relevance for the Brazilian economy, the region is very important from a social point of view because of the large lowincome population living there and its high dependency on production of maize and bean for subsistence. Besides the low productivity, semi-arid crop yield ranges up to 48 percent from one year to another; for example, yield loss was about 80 percent because of the 2012 drought (Conab 2012). This yield variability threatens the sustainability of the communities in this region. For example, according to Medeiros (2013), consequences of droughts and crop losses extend to breakdown of families and social relationships, in part by forced migration to other areas (inside or outside the semi-arid region) in order to search for new job opportunities. While the adaptation options discussed in Section 2 can lessen the indirect impacts, however, as discussed, prioritization in regions is needed for better targeting most exposed municipalities. In the next section, details of the data used and methodology applied in the case study region is given.

\section{DATA USED AND METHODOLOGY APPLIED}

Maize and bean vulnerabilities were assessed via environmental (soil types and number of dry days during the cropping season) conditions, as most other options such as irrigation as well as fertilizer use can be excluded for the SAB as discussed above. The relevant data was taken from official institutions from Brazil such as Brazilian Institute of Geography and Statistics (Ibge), Center for Weather Forecasting and Climate Research of the National Institute for Space Research (Cptec/Inpe), Northeast Real Time Monitoring Programme (Proclima/Cptec/Inpe) and the Soil and Terrain Database for Latin America and 
the Caribbean (Dijkshoorn et al. 2005). Table 1 provides a summary and description of the variables used.

Table 1. Description of the Variables

\begin{tabular}{lllll}
\hline Variable & Unit & Description & Period & Source \\
\hline Crop Yield & $\mathrm{Kg} \mathrm{ha}^{-1}$ & $\begin{array}{l}\text { Produced amount of maize and } \\
\text { bean per area }\end{array}$ & $2005-2012$ & Ibge \\
$\begin{array}{l}\text { Number of } \\
\text { Dry Days }\end{array}$ & day & $\begin{array}{l}\text { Number of days with rain below } \\
1 \mathrm{~mm}\end{array}$ & $2005-2012$ & Proclima \\
$\begin{array}{l}\text { Soil Textural } \\
\text { Class }\end{array}$ & adimensional & Soil textural Class & 1981 & $\begin{array}{l}\text { Dijkshoorn et } \\
\text { al. 2005. }\end{array}$ \\
\hline
\end{tabular}

The data was analyzed at the municipality and sub-regional level. If data on the sub-regional levels was available, we separated also the areas which presented the same soil characteristics. Table 2 presents the numbers attributed to each State and soil condition used for the analysis.

Table 2. Numbers attributed to each State and Soil Class.

\begin{tabular}{cccc}
\hline $\begin{array}{c}\text { Number } \\
\text { attributed }\end{array}$ & State & $\begin{array}{c}\text { Number } \\
\text { attributed }\end{array}$ & Soil textural Class \\
\hline $\mathbf{1}$ & Piauí (PI) & 1 & Clay \\
$\mathbf{2}$ & Ceará (CE) & 2 & Sandy Clay \\
$\mathbf{3}$ & Rio Grande do Norte (RN) & 3 & Sandy Clay Loam \\
$\mathbf{4}$ & Paraíba (PB) & 4 & Sandy Loam \\
$\mathbf{5}$ & Pernambuco (PE) & 5 & Loamy Sand \\
$\mathbf{6}$ & Alagoas (AL) & 6 & Sand \\
$\mathbf{7}$ & Sergipe (SE) & 7 & Clay Loam \\
$\mathbf{8}$ & Bahia (BA) & 8 & Loam \\
$\mathbf{9}$ & Minas Gerais (MG) & 9 & Silty Clay \\
& & 10 & Silty Clay Loam \\
& & 11 & Silty Loam \\
& & 12 & Silt \\
\hline
\end{tabular}

As indicated, our methodology applied here is essentially an empirical one. Our underlying assumption in regards to the vulnerability of agricultural production in the SAB is the dependency of crop yields to weather, especially water deficit during the year. While this is a simplified assumption it may hold true in our case study as all areas are essentially rainfed only and water deficit is the major threat for crop yields. To account for increases in productive area for a given municipality over years, crop yield in kilogram per hectare is used as the dependent variable. Furthermore, soil conditions as well as subregions are used as dummy variables (see Table 2). The data on the municipality level was analyzed 
descriptively (e.g. mean and variation) as well as based on a classic panel regression approach. In more detail a fixed effects model with robust standard errors was used in our case (see Hsiao 2014).

Using this Panel regression approach, the vulnerability of crop yield based on three different perspectives was assessed, including range of potential crop yields, minimum crop yields and stress threshold related yields. In more detail, the first perspective focus on the range of crop yields possible. Therefore, the difference between best and worst outcomes in terms of crop yield for each municipality was selected as the dependent variable. The second perspective looks at minimum crop yields and therefore minimum yields in each municipality were selected for the analysis in order to evaluate the possible worst outcomes (in terms of crop yield). The third perspective is on risk of crop yields and includes a stress threshold to represent real crop resistance (as crops are usually tolerant to a certain level of water deficit). Here we considered the stress threshold as 10 dry days (based on the literature and empirical investigations, one could also interpret this as a very extreme event happening), and we therefore focused on years which had more than 10 dry days within the rainy season. Each one of those perspectives is showing a different dimension of vulnerability to crop production in $\mathrm{SAB}$, useful for different audiences of decision makers. The results of each perspective are shown via the (statistical) significance of parameters to crop yields, e.g. we assume that non-significant results are an indication that for the given region there is no vulnerability (in regards to the independent dimensions such as soil condition or number of dry days) to crop production. Given there is significance found, the (normalized) coefficients of each region are compared with to evaluate which regions are more vulnerable. In a final step, the probability of falling below a given crop yield threshold level was estimated which provides additional information about risk across regions. Again, referring to the IPCC (2012) definition of risk, also here risk is defined as the product of the probability that some event will occur and the adverse consequences of that event (IPCC 2012). A gamma distribution for number of dry days (this distribution is also commonly used to model cumulative rainfall, see Husak et al. 2007) was selected to estimate the event probabilities for each perspective.

\section{RESULTS}

We start with some overall information of crop yields based on the time-series (Table 1). Figure 3 presents mean and standard deviations of maize and bean yields for the respective regions (States). As one can see, the mean (represented by circles) is small in most states which can be attributed to irregularity of precipitation during the crop season, poor soil conditions as well as the low technologic levels adopted for farming there. The standard deviation (represented by bars) is very large in most of the states and shows the potential large year by year variations in crop yields. These observations are in line with the previous discussions in section 2 and 3, i.e. low average crop yields but high annual variability. 


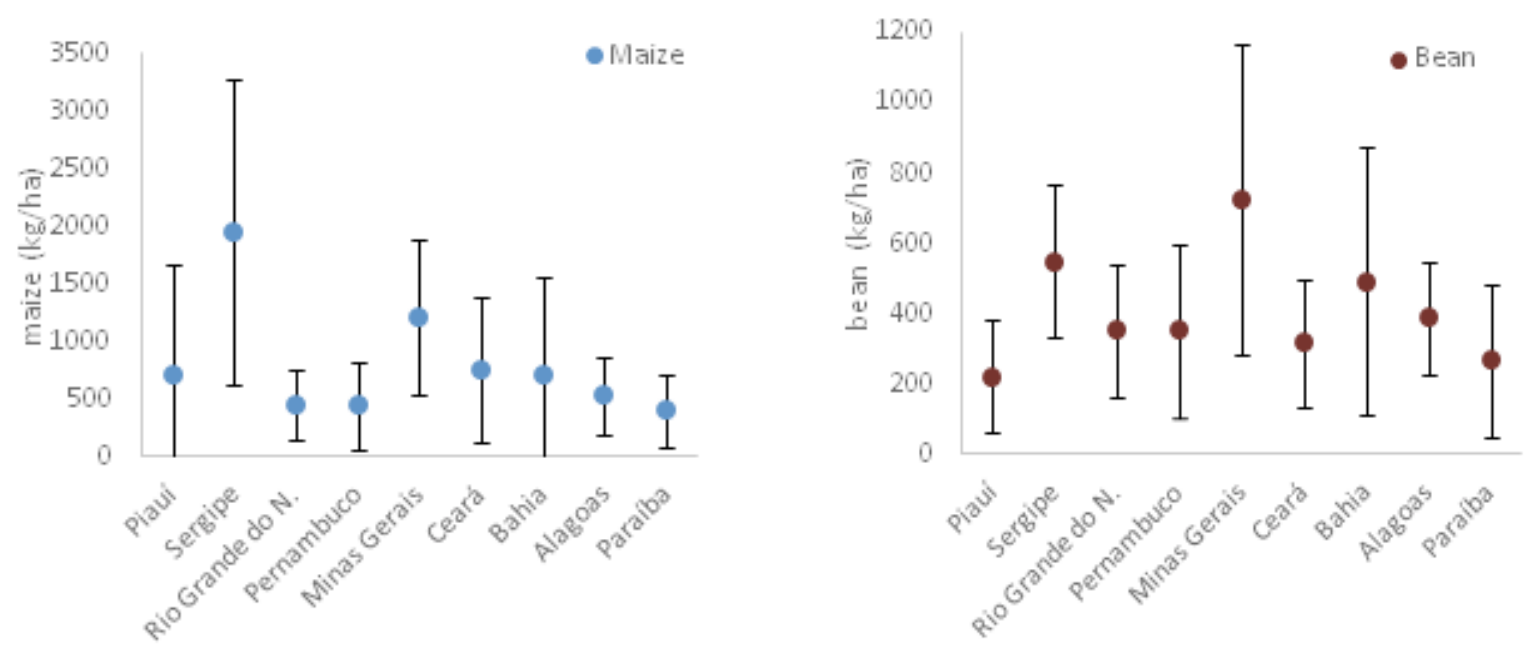

Figure 3. Mean and Standard Deviation of maize and bean crop yield for each State comprised by SAB.

The significant dimensions for each sub-region as well as the estimated coefficients and the fit of the model to data via the panel regression approach can be found in Appendix A. Here we present the results from a geographical point of view for our aforementioned perspectives as this indicates better the regions with high vulnerability. To start with, Figure 4 shows the municipalities were crop production was found to be significantly (p-value $<0.05$ ) vulnerable to number of dry days and soil conditions. This does not necessarily mean that the other areas are not actual vulnerable, additional information on these regions or selecting larger thresholds for the p-value can eventually lead to an increase of areas (see Appendix A).

$1^{\text {st }}$ Perspective

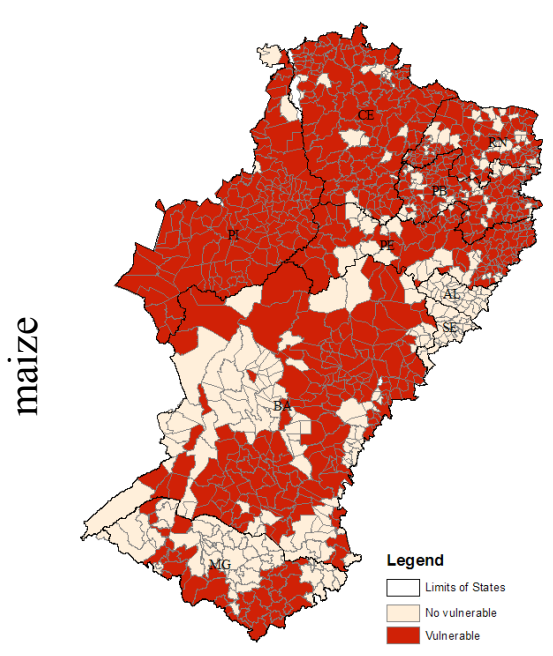

$2^{\text {nd }}$ Perspective

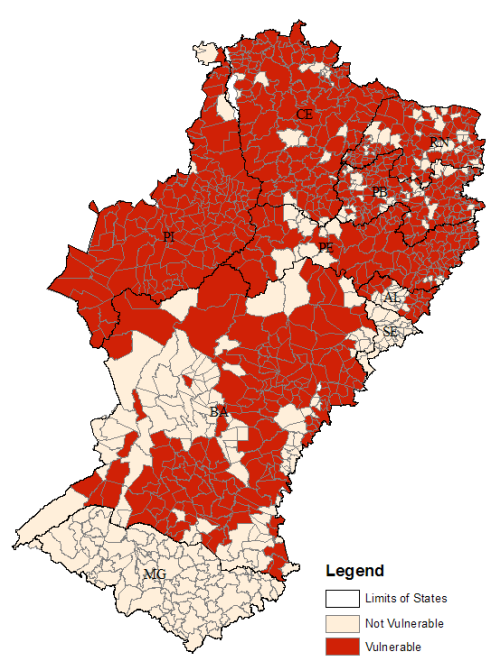

$3^{\text {rd }}$ Perspective

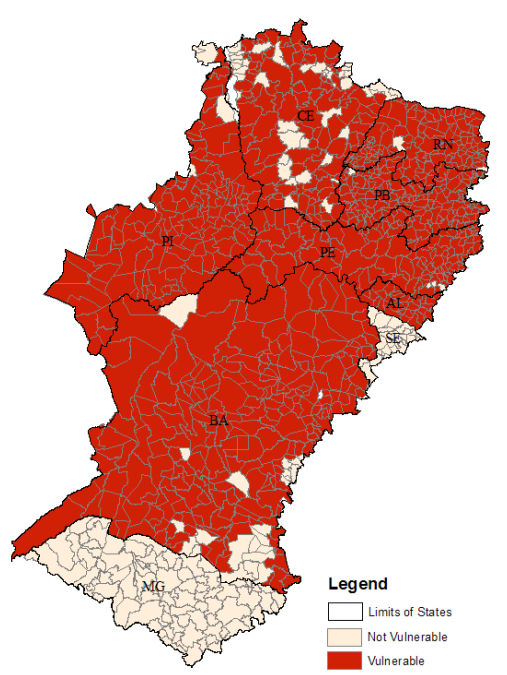



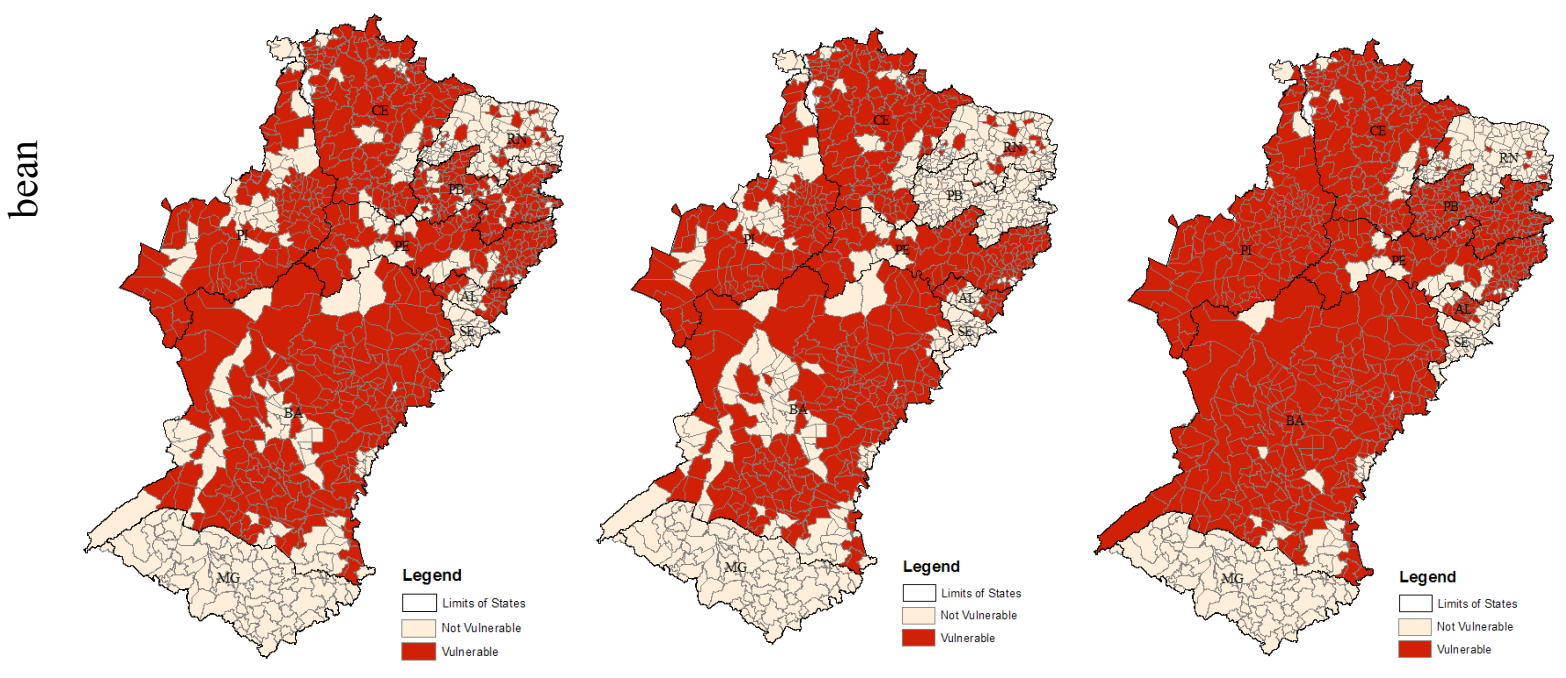

Figure 4. Vulnerability of maize and bean crop production according to three perspectives. $1^{\text {st }}$ perspective is on range of crop yields, $2^{\text {nd }}$ perspective is on minimal yields and $3^{\text {rd }}$ perspective on thresholds.

For example, the municipalities which showed significant vulnerability accounted to 68,54 and 77 percent of all municipalities, considering the $1^{\text {st }}, 2^{\text {nd }}$ and $3^{\text {rd }}$ perspectives, respectively. Note, the analysis was performed for all three perspectives and showed different vulnerabilities for maize and bean yield. This is due to the different resistance of each of the crops to water deficit and the different dimensions of vulnerability considered. It should be noted that most of the municipalities which did not showed any vulnerability are in the southern part of the region, i.e. farther away from the Equator line. The high percentage of total municipalities which showed their agriculture production affected by dry days and soil condition in all the three perspectives also signifies the extension of vulnerability in that region and the influence of environmental conditions for agriculture.

In a next step and in order to compare vulnerability of crop yields to the weather and soil variables for different municipalities the beta coefficient from the regression results (see Appendix A) was standardized as well as categorized for comparison reasons. Vulnerability in Figure 5 ranges from 0 (light orange), meaning no vulnerable, to 1 (dark orange), indicating the highest vulnerability. Again, Figure 5 shows the vulnerability in SAB for all three perspectives.

As can be seen, the most vulnerable areas are in the Northern part. Even though in the southern part there are some municipalities with high vulnerability, whereas the latitude increases (in absolute values) the amount of high vulnerable municipalities also drops down. While the results above are on the subregional level, in order to compare our results with other indices developed in our study area, also the states are looked at, mainly since most studies used state level information to delimit their analysis. As one can see in Figure 5, the highest indices of vulnerability can be found in the region of Piauí (PI), Ceará (CE), Pernambuco (PE) and Paraíba (PB), showing only small variation depending upon the perspective and crop analyzed.

The vulnerability of crop production corresponds directly to the food security of the respective communities. For example, there is a strong agreement between those states which presented highest vulnerability and the states which presented the highest Food Insecurity Indices. For example, according to the official statistics about Food Security in Brazil (Ibge 2013), Piauí (PI) presented the second worst Food Security Index. Only 44 percent of the total population experiences no problems with food supply, while the Brazil average is about 77 percent. Ceará (CE), Pernambuco (PE) and Paraíba (PB) are also below Brazils' average having a Food Security Indices of 64, 74 and 63 percent, respectively. 
$1^{\text {st }}$ Perspective
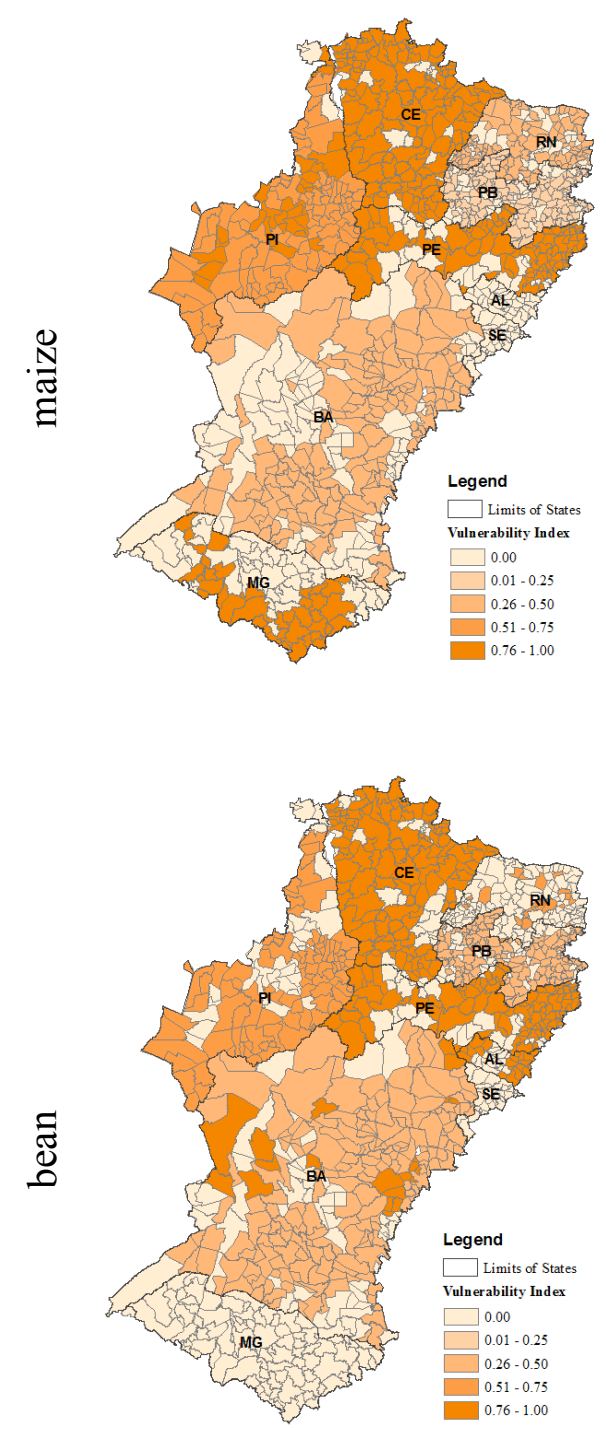

$2^{\text {nd }}$ Perspective
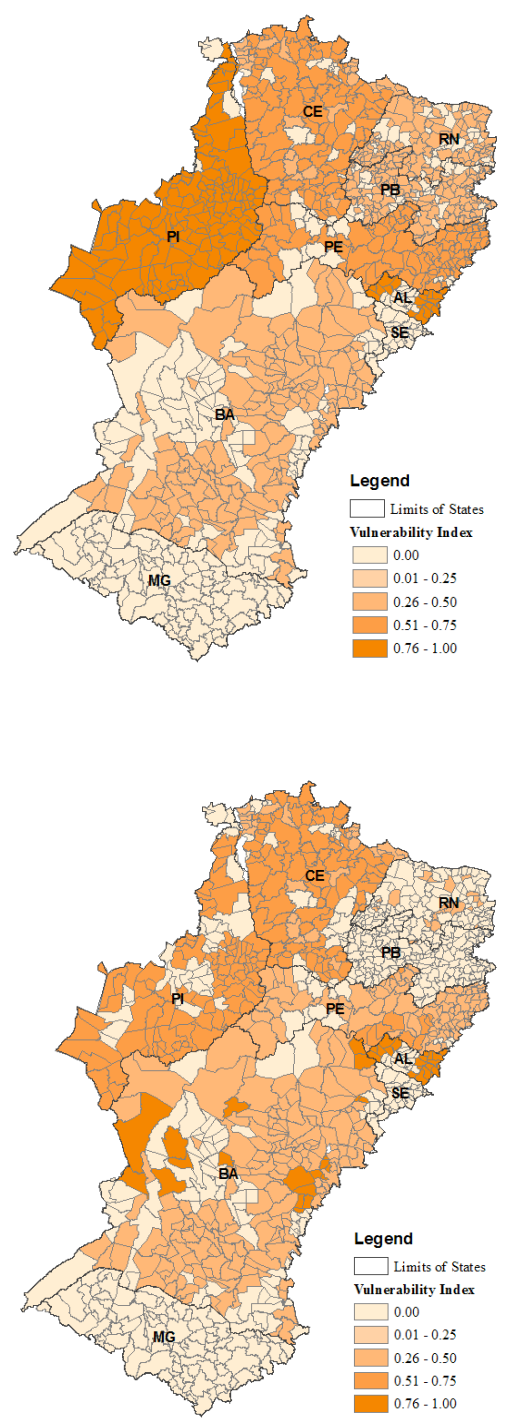

$3^{\text {rd }}$ Perspective
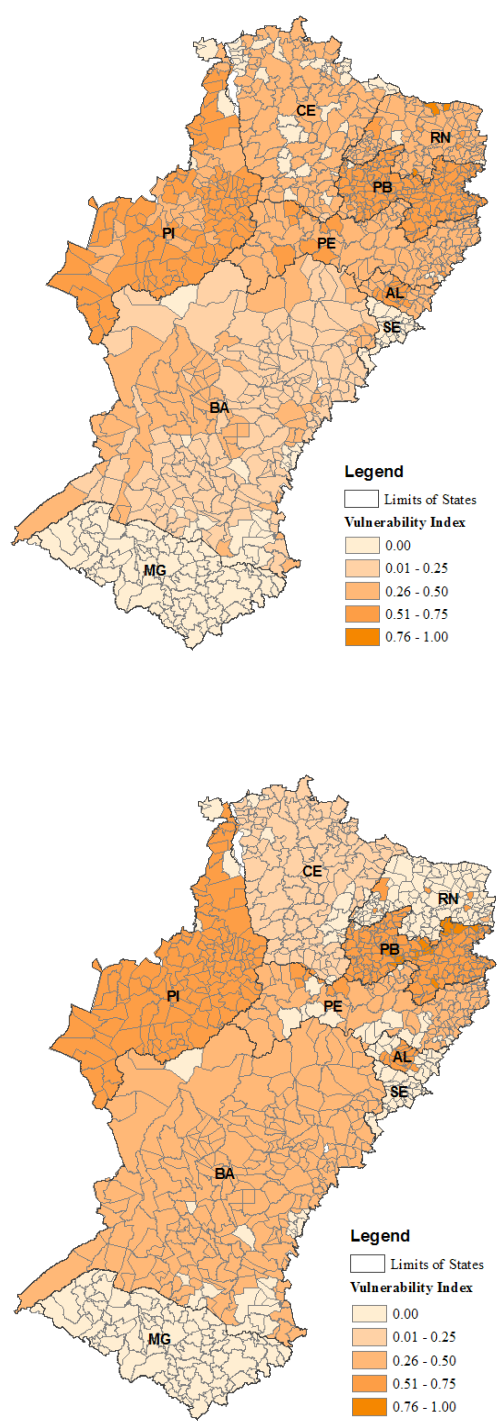

Figure 5. Vulnerability of maize and bean production according to the three perspectives.

Furthermore, if the Vulnerability Index is compared with a Crop Loss Index, it also shows good agreement. For example, Piauí (PI) had in 2002, the last year the Crop Loss Index was assessed, the worst Crop Loss Index: about 52 percent of crop loss for maize and 42 percent of crop loss for bean (Ibge 2004). These results suggest that, the vulnerability condition has been present since a considerable time and the community and the government have not yet applied an efficient response in order to lessen the vulnerability of those regions.

Finally, in a last step, for those municipalities which showed significant vulnerability in crop production according to Figure 4, a probabilistic risk analysis was additionally performed in the following way: First, municipalities in sub-regions were grouped according to its State and soil condition. 
Afterwards, a gamma distribution was estimated based on past observations of number of dry days in the particular sub-region. To decrease the absolute range of crop yields for the different perspectives all crop yield values were transformed to logarithmic scale. In more detail, for the first perspective the difference between natural logarithmic of highest crop yield and natural logarithmic of lowest crop yield for each municipality was used. For the other two perspectives the exponential function was used. We identify each sub-region using two numbers, for example 13 means, State 1 and Soil condition 3 (see Table 2). For each one of the three perspectives, the exceedance curve of the gamma distribution and also the corresponding table with risks in terms of exceeding a given threshold level (on the right-hand side of the Figure) is given. In Figure 6 for example the threshold was defined as having more than 20 dry days. Consequently, the risk (in terms of probability) that in a given year in a given sub-region more than 20 dry days will be observed is shown and additionally the consequence in terms of decrease in crop production for all three perspectives given (see Appendix B for the second and third perspective).

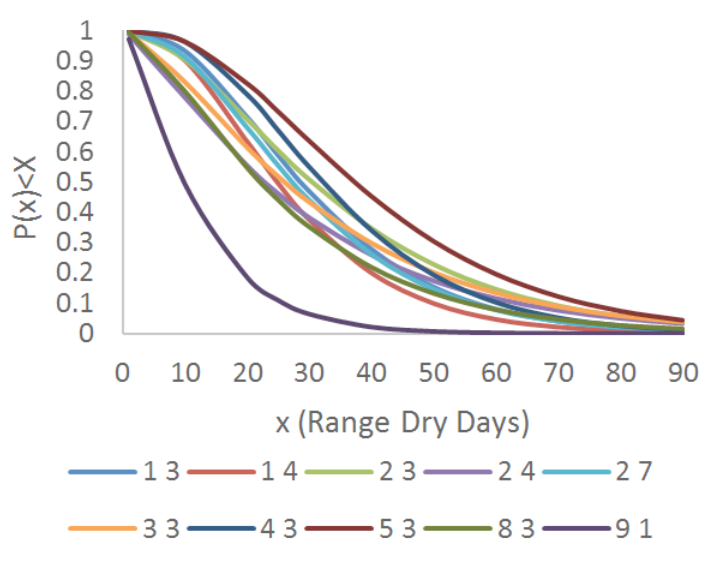

\begin{tabular}{ccc}
\hline Sub-region & $\mathbf{P}(\mathbf{x}>\mathbf{2 0})$ & $\begin{array}{c}\text { Crop } \\
\text { Loss }\end{array}$ \\
\hline $\mathbf{1 3}$ & $71 \%$ & $91.7 \%$ \\
$\mathbf{1 4}$ & $63 \%$ & $91.1 \%$ \\
$\mathbf{2 3}$ & $71 \%$ & $87.8 \%$ \\
$\mathbf{2 4}$ & $55 \%$ & $85.1 \%$ \\
$\mathbf{2 7}$ & $68 \%$ & $82.4 \%$ \\
$\mathbf{3 3}$ & $61 \%$ & $75.7 \%$ \\
$\mathbf{4 3}$ & $79 \%$ & $86.4 \%$ \\
$\mathbf{5 3}$ & $83 \%$ & $74.7 \%$ \\
$\mathbf{8 3}$ & $55 \%$ & $85.3 \%$ \\
$\mathbf{9 1}$ & $19 \%$ & $77.1 \%$ \\
\hline
\end{tabular}

Figure 6. Risk analysis for maize $\left(1^{\text {st }}\right.$ perspective $)$

In Appendix $\mathrm{C}$ the risk analysis for bean production can be found too. Interestingly, as one can see in Figures B1 and C.1 (Appendix B and C), different crops can have different risks and consequences for yields. For example, for maize and the first perspective, sub-region 13 shows that with 71 percent probability one can expect more than 20 dry days annually and expected crop loss would be about 90 percent. In the same sub-region, but now for bean, the risk is much larger (about 79 percent) but crop loss lower ( 86 percent). For the $2^{\text {nd }}$ perspective, taking the sub-region 13 again as an example, the probability is around 80 percent and minimum crop yield of about $125 \mathrm{~kg} / \mathrm{ha}$ for maize can be expected. For bean the risk is larger than for maize (about $90 \%$ ) and the minimum crop yield could be the half of the minimum crop yield expected for maize $(66.4 \mathrm{~kg} / \mathrm{ha}$ ). Both expected yields (for bean and maize) are insufficient to feed the families who depend on this production for their subsistence.

As indicated, in the third perspective a stress threshold was included and only years with more than 10 dry days in its rainy season were included in the analysis. The probability of a certain year to have more than 20 dry days in its rainy season is about 80 percent for maize and bean. However the consequences are very different. While maize can have a yield of about $387 \mathrm{~kg} / \mathrm{ha}$, with 20 dry days in the complete season, bean production can be expected to be around only $192 \mathrm{~kg} / \mathrm{ha}$. Also here, despite maize and bean present different productive potentials, the expected yields are below the required amount to feed families. Summarizing, the consequences on crop production have ranged from only small losses till complete crop failure. Nevertheless, those consequences on crop production, presented in Figure 6, B1.2 and C, could 
become even worse if one considers the projections of dry days in the future. According to Polade et al. (2014) the frequency of dry days per year for Brazilian Northeast trends to increase to about 20 more dry days per year, over the period 2060-2089, relative to the historical period (1960-1989). Hence, the estimates presented here can be used to perform some sensitivity tests about the potential consequences in terms of agricultural production for the respective municipalities in the SAB for future climate which will be discussed in more detail next.

\section{DISCUSSION}

This paper focused on the vulnerability and risk of crop production. In the analysis soil textural classes and number of dry days represented some reasonable variables for determining crop production vulnerability and risk. Based on the analysis, hotspot areas were identified which may help to prioritize those municipalities most in need to decrease current and future vulnerability. In addition, the risk analysis may help policy makers to choose the correct municipalities to apply actions towards mitigation and adaptation to rainfed agriculture in a more complex setting taking both probabilities of weather events as well as corresponding consequences into account. Surprisingly, many municipalities showed strong dependency on climate related variables which is in accordance to similar studies done on the state level.

Considering climate change as a fact and already affecting several regions over the world (Magrin et al. 2014) many studies have designed indices with the objective to indicate the degree of future susceptibility or vulnerability to climatic extremes in a given region (Baetting et al. 2007; Confolarieri et al. 2009; 2014). For example, Baetting et al. (2007) has shown that the Northern (Amazon) and Northeastern regions for Brazil were considered as "Hotspots", because of the high magnitude of the expected changes in future climate. Also, the National Institute for Space Research (INPE) in Brazil has focused on projecting changes in climate for several Brazilian regions (Marengo et al. 2009; Marengo 2009; Marengo et al. 2011; Chou et al. 2012). Using Regional climate models, those studies have found an increase in air temperature and reduction in precipitation, resulting in increased evaporation, reduction in water storage in the soil and deficits in the water balance. Considering the $\mathrm{B} 2$ scenario, the regional warming could reach $2-3^{\circ} \mathrm{C}$, up to the end of the XXI century. Regarding the A2 scenario the regional warming could reach up to $4^{\circ} \mathrm{C}$ and negative rainfall anomalies were expected to be around $2.4 \mathrm{~mm} /$ day (Marengo et al. 2007; Ambrizzi et al. 2007). This would cause a worsening of the aridity and therefore will cause an increase in vulnerability.

Considering A2 and B2 scenarios as mentioned above, Confolarieri et al. (2014) designed a composite vulnerability index to climate change in the Brazilian Northeastern Region. Although this study took into account a larger number of indicators, some agreements between the most vulnerable regions in our study and the index developed by Confolarieri et al. (2014) can be found. For example, the general vulnerability index (IVG) showed that Ceará (CE) and Pernambuco (PE) states were considered to be most vulnerable as they presented the higher IVG values under both climatic scenarios. Ceará (CE) and Pernambuco (PE) also presented high values of vulnerability but, under current climatic condition, as one can see in Figure 6. The agreement of these studies indicate that the current and future assessments could be complementary, increasing the confidence of results and helping stakeholders to detect hotspots and applying efficient adaptation and mitigation actions taking into account the current and future vulnerability. An iterative risk management approach with updated information on a continuous basis and an ensemble of different modelling approaches and risk measures may provide a viable way forward to target this complex issue on the policy level (Schinko et al. 2016).

It should be noted that many studies have presented different methodologies to assess vulnerability of crop production over the world. Some by quantitative crop modeling approaches, such as Challinor et al. (2010); Fraser et al. (2013); Simelton et al. (2012) and others by indicators such as Antwi-Agyei et al. (2012); Lindoso et al. (2014); Xu et al. (2012). Contrary to these studies this paper highlighted the risk 
component (in terms of probability of low crop yields) and focused on the full spectrum of possible crop outcomes. States with highest vulnerability risk indices were Ceará (CE), Piauí (PI), Pernambuco (PE) and Paraíba (PB). Those states are also presented in other studies as critical in terms of vulnerability according to future climate (Confolarieri et al. 2014), food security (Ibge 2013) and crop loss (Ibge 2004). Regarding actual adaptation measures using the results found, several observations can be made. For example, in case of food shortages, migration is the main mechanism by families to guarantee food security, and our results could allow stakeholders evaluate several sub-regions in SAB and apply policies to reduce the need for rural to urban migration. Confolarieri et al. (2014) point out some policies such as the conservation and provision of water resources and government-sponsored temporary jobs to reduce the intensity of rural migration. It should be noted that although the Brazilian Government has applied some actions towards to adaptation, additional policies could be applied in order to subsidize crop insurance, agricultural risk zoning, sustainable soil management and improvement of risk management strategies. The results presented in this work can be seen as one part of the adaptation puzzle and may help policy makers to formulate more specific adaptation policies to decrease the vulnerability of small households whose livelihoods depend mostly on rainfed agriculture.

Furthermore, stakeholders may use the probabilistic risk analysis to estimate the effects of droughts in each region and to prioritize emergency actions on the most vulnerable municipalities. For example, the risk (in terms of probability) for more than 20 days without rain and estimated consequences in terms of crop loss can be used for emergency planning. The intensity of these consequences on crop yield and, consequently, on population, could determine the urgency and the kind of actions required. Even though there is long experience in Brazil with emergency drought actions, advance planning is required because the spatial and temporal patterns of droughts in the regions differ from one event to the other; consequently, to meet the requirements of local communities it is necessary to adapt fast to current and changing circumstances. Hence, in a next step, other components of vulnerability such as those related to sensibility and adaptive capacity will be incorporated to improve the analysis and setting priorities. An iterative risk management approach may be beneficial in that regard.

\section{REFERENCES}

Alexandratos, N. and J. Bruinsma. (2012). World Agriculture Towards 2030/2050: The 2012 Revision. ESA Working Paper No. 12-03. Rome: United Nations FAO.

Ambrizzi, T., Rocha, R., Marengo and J.A., Pisnichenko, I.; Alves, L.M. and Fernandez, J.P.R. (2007) Cenários regionalizados de clima no Brasil e América do Sul, para o século XXI: Projeções de clima futuro usando três modelos regionais. [Portuguese] 112p.São Paulo. Available at: http://www.grec.iag.usp.br/link grec_old/outros/ambrizzi/relatorio3.pdf.

Antwi-Agyei, P., Fraser, E.D.G., Dougill, A.J., Stringer, L.C. and Simelton, E. (2012) Mapping the vulnerability of crop production to drought in Ghana using rainfall, yield and socioeconomic data. Applied Geography, 32, pp. 324-334.

Baettig, M.B.; Wild, M. and Imboden, D.M. A. (2007). climate change index: Where climate change may be most prominent in the 21st century. Geophysical Research Letters, vol. 34, L01705, doi:10.1029/2006GL028159

Banco do Nordeste. [Bank of Northeast]. (2010) Agricultura familiar no Nordeste. Informe Rural Etene. Year 4, no5. [Portuguese] Available at: http://www.bnb.gov.br/documents/76079/226493/ETENEano4 5.pdf/0f571905-3912-48bd-b56b-b30d96c91273.

Berlato, M.A., Farenzena, H. and Fontana, D.C.(2005) Associação entre El Niño Oscilação Sul e a produtividade do milho no Estado do Rio Grande do Sul. [Association between El Niño Southern Oscillation and corn yield in Rio Grande do Sul State]. Pesquisa agropecuária brasileira. 
[Portuguese].v.40, no 5, pp. 423-432.

Brazil (2013) Observatório das Secas. Available at: http://www.brasil.gov.br/observatoriodaseca/.

Challinor, A.J., Simelton, E.S., Fraser, E.D.G., Hemming, D. and Collins, M. (2010) Increased crop failure due to climate change: assessing adaptation optionsusing models and socio-economic data for wheat in China. Environmental Research Letters, v.5. no3, 8pp.

Chou, S.C., Marengo J.A., Lyra, A. Sueiro, G.; Pesquero, J.F.; Alves, L.M.; Kay, G.; Betts, R. Chagas, D.J.; Gomes, J.L.; Bustamante, J. F.; and Tavares, P. (2012) Downscaling of South America present climate driven by 4member HadCM3runs. Clim Dyn 38(3/4):635-653.

Companhia Nacional de Abastecimento (Conab). 2012. Acompanhamento de Safra Brasileira: Gãos, décimo levantamento. Julho/2012. Brasília.

Confalonieri, U.E.C., Marinho, D.P.and Rodriguez, R.R. (2009). Public Health Vulnerability to climate change in Brazil. Clim Res 40:175-186.

Confalonieri, U.E.C., Lima, A.C.L., Brito, L. and Quintão, F. (2014). Social, environmental and health vulnerability to climate change in the Brazilian Northeastern Region. Climatic Change .127:123-13.

Dijkshoorn, J.A, Huting J.R.M. and Tempel. P. (2005) Update of the 1:5 million Soil and Terrain Database for Latin America and the Caribbean (SOTERLAC; version 2.0). Report 2005/01, ISRIC World Soil Information, Wageningen. Avaiable at http://www.isric.org/isric/webdocs/docs/ISRIC Report 2005 01.pdf

Evidence and lessons from Latin America (Ella). (2011) Improving Small Farmers' Adaptive Capacity in Semi-arid Regions. 2011. Available at: http://r4d.dfid.gov.uk/pdf/outputs/ELLA/111104 ENV AdaSemReg GUIDE.pdf.

Fonseca, J.E., Carneiro, M., Pena, J.L., Colosimo, E.A., Silva, N.B.D., Costa, A.G.F.C., Cairncross, S. and Heller, L. (2014) Reducing Occurrence of Giardia duodenalis in Children Living in Semiarid Regions: Impact of a Large Scale Rainwater Harvesting Initiative. PLoS Neglected Tropical Disease $8(6)$.

Fraser, E.D.G., Simelton, E., Termansen, M., Gosling, S.N. and South, A. (2013) Vulnerability hotspots: Integrating socio-economic and hydrological models toidentify where cereal production may decline in the future due to climate change induced drought. Agricultural and Forest Meteorology. 170. pp.195-205.

Husak, G. J., Michaelsen, J. and Funk, C. (2007). Use of the gamma distribution to represent monthly rainfall in Africa for drought monitoring applications. International Journal of Climatology, 27(7), 935-944.

Hsiao, C. (2014) Analysis of Panel Data. $3^{\text {rd }}$ edition. Cambridge University Press.

Instituto Brasileiro de Geografia e Estatística- [Brazilian Institute of Geography and Statistics] (Ibge). (2015) Produção Agrícola Municipal. 2014. Rio de Janeiro. Available at: http://www.sidra.ibge.gov.br/bda/tabela/protabl.asp?c=1002\&z=t\&o=28\&i=P.

Instituto Brasileiro de Geografia e Estatística- [Brazilian Institute of Geography and Statistics] (Ibge). (2013) Pesquisa Nacional de Amostra de Domicílios: Segurança Alimentar. Rio de Janeiro. Available at: ftp://ftp.ibge.gov.br/seguranca alimentar 2013/pnad2013 seguranca alimentar.pdf.

Instituto Brasileiro de Geografia e Estatística- [Brazilian Institute of Geography and Statistics] (Ibge). (2012) Censo 2010. Rio de Janeiro. Available at: http://www.ibge.gov.br/home/estatistica/populacao/censo2010/default.shtm.

Instituto Brasileiro de Geografia e Estatística- [Brazilian Institute of Geography and Statistics] (Ibge). 
(2004) Indicadores agropecuários 1996-2003 / IBGE, Coordenação de Agropecuária. - Rio de Janeiro.

IPCC (2012) Managing the risks of extreme events and disasters to advance climate change adaptation In: Field CB, Barros V, Stocker TF, Qin D, Dokken DJ, Ebi KL, Mastrandrea MD, Mach KJ, Plattner G-K, Allen SK, Tignor M, Midgley PM (eds) A special report of working groups I and II of the intergovernmental panel on climate change. Cambridge University Press, Cambridge

Krol, M.S., Jaeger, A., Bronstert, A. and Guentneir. (2006) Integrated modeling of climate, water, soil, agricultural and socio-economic processes: A general introduction of the methodology and some exemplary results from the semi-arid north-east of Brazil. Journal of Hydrology, 328(3-4),pp. 417-431.

Krol, M.S. and Bronstert, A. (2007) Regional integrated modeling of climate change impacts on natural resources and resource usage in semi-arid Northeast Brazil. Environmental Modelling \& Software v22, pp 259-268.

Lindoso, D.P., Rocha, J.D., Debortoli,N., Parente, I.I., Eiró, F., Bursztyn, M. and Rodrigues-Filho, S. (2014) Integrated assessment of smallholder farming's vulnerability to drought in the Brazilian Semiarid: a case study in Ceará. Climatic Change.

Magrin, G., Marengo, J., Boulanger, J.P., Buckeridge, M.S., Castellanos, E., Poveda, G., Scarano, F.R. and Vicuña, S. (2014) Central and South America. In: Climate Change 2014: Impacts, Adaptation and Vulnerability. Contribution of Working Group II to the Fifth Assessment Report of the Intergovernmental Panel on Climate Change. In Press, Cambridge University Press, Cambridge, UK.

Marengo, J.A.; Torres, R.R. and Alves, L.M. (2016). Drought in Northeast Brazil-past, present, and future. Theor Appl Climatol. doi 10.1007/s00704-016-1840-8.

Marengo, J.S.C., Chou, G., Kay, G.; Alves, L.A.; Pesquero, J.F.; Soares, W.R.S.; Santos, D.C.; Lyra, A.A.; Sueiro, G. Betts, R.; Chagas, D. J.; Gomes, J.L.; Bustamante, J.F. and Tavares, P. (2011) Development of regional future climate change scenarios in South America using the Eta CPTEC/HadCM3 climate change projections: Climatology and regional analyses for the Amazon, São Francisco and the Paraná River Basins. Clim Dyn. doi:10.1007/s00382-011-1155-5.

Marengo, J.A., Alves, L.M., Beserra, A.E.and Lacerda, F.F. (2011) Variabilidade e mudanças climáticas no semiárido brasileiro. Instituto Nacional do Semiárido. Campina Grande - PB.

Marengo, J.A. (2009). Vulnerability, impacts and adaptation (VIA) to climate change in the Semi-Arid region of Brazil. In: Brazil and climate change: vulnerability, impacts and adaptation. Brasilia CGEE, pp 137-164.

Marengo, J.A., Ambrizzi,T., Rocha, Alves, M.M., Alves, L.M., Cuara, S.V.; Valverde, M.C.; Torres, R.P.; Santos, D.C. and Ferraz, S.E.T. (2009) Future change of climate in South America in the late twenty first century: intercomparison of scenarios from three regional climate models. Clim Dyn 35(6):1073- 1097.

Marengo, J.A. (2008) Vulnerabilidade, impactos e adaptação à mudança do clima no semi-árido do Brasil. Parcerias estratégicas. Brasília, DF, no 27.

Marengo, J.A., Nobre, C.A., Salatiet, E. and Ambrizzi, T. (2007) Caracterização do clima atual e definição das alterações climáticas para o território brasileiro ao longo do século XXI: sumário técnico. São Paulo: CPTEC/INPE; IAG/USP; Rio de Janeiro: FBDS, pp 54.

Martins, M A. (2012) Estimativa da produtividade das culturas de milho e sorgo na região Semi-árida do Brasil. [Estimate of crop yield of maize and sorghum by agrometeorological models in locations of Northeast Brazil]. Dissertation. Master in Meteorology. National Institute for Space Research, [Portuguese].127p. Avaiable at: http://urlib.net/8JMKD3MGP8W/3BBGU25.

Medeiros, S.S., Marin, A.M.P., Reis, C.F., Soriano, J.J., Santos, D.B. and Pereira, D.D.(2013) Estiagem e 
Seca no Semiárido Brasileiro. Folheto Informativo no 1, INSA.

Moura, A.D. and Shukla, J. (1981) On the dynamics of the droughts in Northeast Brazil: observations, theory and numerical experiments with a general circulation model. Journal Atmospheric Science, v 38, no 12, pp 2653-2673.

Moura, M.S.B., Galvincio, J.D. Brito, L.T.L., Souza, L.S.B., Sá, I.I.S. and Silva, T .G. F.(2007) Clima e água de chuva no semi-árido. In Potencialidades da água de chuva no Semi-árido brasileiro. Brito, LTL, Moura, MSB, Gama, GFB. (Ed.). Petrolina:Embrapa Semi-árido.

Morrison, C. (2010) Seca, o semi-árido, e o pequeno agricultor em Canindé, Ceará. In: Depois que a chuva não veio - Respostas sociais às secas na Amazônia, no Nordeste, e no Sul do Brasil. Addei, R, Gamboggi, A. Fundação Cearense de Meteorologia e Recursos Hídricos, Instituto Comitas para Estudos Antropológicos. . Rio de Janeiro: pp 137-176.

Nobre, C.A. (2014) Climate Prediction and Drought Policies in Brazil: the experience of 2012-2013. Presentation in Adaptation Futures Conference. Fortaleza, Brazil.

Polade, S.D., Pierce, D.W., Cayan, D.R., Gershunov,A. and Dettinger, M,D. (2014) The key role of dry days in changing regional climate and precipitation regimes. Scientific Reports. $4: 4364$ doi:10.1038/srep04364.

Ropelewski, C.F. and Halpert, M.S. (1989) Precipitation patterns associated with the high index phase of the southern oscillation. Journal of Climate, v 2, pp 268-284.

Schinko, T., Mechler, R. and Hochrainer-Stigler, S. (2016). A methodological framework to operationalize climate risk management: managing sovereign climate-related extreme event risk in Austria. Mitigation and Adaptation Strategies for Global Change, doi: 10.1007/s1 1027-016-9713-0

Serra, A.B. (1941) The general circulation over South America. Bulletin of the American Meteorological Society, v22, pp173-179.

Silva, V.P.R., Guedes, M.J.F., Lima, W.F.A. and Campos, J.H.B.C. (2002) Modelo de previsão de rendimento de culturas de sequeiro, no semi-árido do Nordeste do Brasil. [A forecast model for yield of rainfed crops grown in semi-arid Northeast Brazil] Rev. Bras. Eng. Agríc. Ambient. [online]. v 6, no 1, pp 83-87.

Simelton, E., Fraser, E.D.G., Termansen, M., Benton, T.G., Gosling, S.N., South, A., Arnell, N.W., Challinor, A.J., Dougill, A.J. and Forster, P.M. (2012) The socioeconomics of food crop production and climate change vulnerability: a global scale quantitative analysis of how grain crops are sensitive to drought. Food Security. 4:163-179.

Simões, A.F, Kligerman, D.C., La Rovere, E.L., Moroun, M.R., Barata,M. and Obermaier,M. (2010) Enhancing adaptive capacity to climate change: The case of smallholder farmers in the Brazilian semiarid region. Environmental Science \& Policy, V.13, pp.801-808.

United Nations. United Nation Decade: For Deserts and fight against desertification. (2011) Available at: http://www.un.org/en/events/desertification decade/whynow.shtml.

UN (United Nations). (2015a). Sustainable Development Goals. United Nations. Available at https://sustainabledevelopment.un.org/?menu1/41300〉 Accessed 1.2.2017).

UN (Nations United). (2015b). Transforming our world: The 2030 agenda for sustainable development." New York: United Nations, Department of Economic and Social Affairs.

UNISDR (United Nations International Strategy for Disaster Reduction). (2015). Sendai framework for disaster risk reduction 2015-2030. Geneva: UNISDR.

Xu, W., Ren , G., Johnston, T., Yin.W., Klein, K., Smith, A. (2012) Spatial and temporal variation in 
vulnerability of crop production to drought in southern Alberta. The Canadian Geographer.56(4), pp. 474-491.

World Economic Forum (2017). The Global Risks Report 2016. Geneva, Switzerland. Available at : http://www3.weforum.org/docs/GRR/WEF_GRR16.pdf (Accessed 1. February 2017).

WRI (World Resources Institute) (2013). World Resources Report 2013-2015: Creating a Sustainable Food Future. Washington, DC: World Resources Institute. http://www.wri.org/ourwork/project/world-resources-report/world-resources-report-2013-2015-creating-sustainable-food. 
Appendix A: Statistical parameters

Table A.1. Statistical parameters from Panel Regression considering maize production

\begin{tabular}{|c|c|c|c|c|c|c|c|c|c|c|c|c|}
\hline \multicolumn{13}{|c|}{ Statistical parameters maize } \\
\hline \multirow{2}{*}{$\begin{array}{c}\text { Sub } \\
\text { Region }\end{array}$} & \multicolumn{4}{|c|}{$1^{\text {st }}$ Perspective } & \multicolumn{4}{|c|}{$2^{\text {nd }}$ Perspective } & \multicolumn{4}{|c|}{$3^{\text {rd }}$ Perspective } \\
\hline & p-value & $\beta$ & $\beta_{\mathrm{s}}$ & $\mathrm{r}^{2}$ & p-value & $\beta$ & $\beta \mathrm{s}$ & $r^{2}$ & p-value & $\beta$ & $\beta \mathrm{s}$ & $r^{2}$ \\
\hline 13 & $0.000 *$ & 0.018 & 0.750 & 0.205 & $0.000^{*}$ & -0.02 & 0.862 & 0.24 & $0.000 *$ & -0.06 & 0.54 & 0.465 \\
\hline 14 & $0.000^{*}$ & 0.021 & 0.875 & 0.444 & $0.020^{*}$ & -0.02 & 1.000 & 0.31 & $0.000^{*}$ & -0.05 & 0.48 & 0.341 \\
\hline 17 & 0.419 & - & 0.000 & - & 0.489 & - & 0.000 & - & 0.095 & - & 0.00 & - \\
\hline 21 & 0.175 & - & 0.000 & - & - & - & 0.00 & - & 0.304 & - & 0.00 & - \\
\hline 22 & 0.092 & - & 0.000 & - & 0.185 & - & 0.00 & - & 0.090 & - & 0.00 & - \\
\hline 23 & $0.000^{*}$ & 0.021 & 0.875 & 0.340 & $0.000^{*}$ & -0.02 & 0.690 & 0.27 & $0.000^{*}$ & -0.03 & 0.34 & 0.248 \\
\hline 24 & $0.000^{*}$ & 0.019 & 0.792 & 0.746 & $0.020^{*}$ & -0.01 & 0.345 & 0.25 & 0.060 & - & 0.00 & - \\
\hline 25 & - & - & 0.000 & - & - & - & 0.000 & - & 0.759 & - & 0.00 & - \\
\hline 27 & $0.001^{*}$ & 0.024 & 1.000 & 0.736 & $0.030^{*}$ & -0.02 & 0.690 & 0.69 & $0.012 *$ & -0.03 & 0.26 & 0.169 \\
\hline 28 & - & - & 0.000 & - & - & - & 0.000 & - & $0.038^{*}$ & -0.02 & 0.23 & 0.482 \\
\hline 31 & 0.350 & - & 0.000 & - & 0.354 & - & 0.000 & - & $0.000^{*}$ & -0.11 & 1.00 & 0.707 \\
\hline 32 & - & - & 0.000 & - & - & - & 0.000 & - & - & - & 0.00 & - \\
\hline 33 & $0.012^{*}$ & 0.007 & 0.292 & 0.061 & $0.020^{*}$ & -0.00 & 0.276 & 0.08 & $0.000^{*}$ & -0.03 & 0.31 & 0.111 \\
\hline 34 & 0.420 & - & 0.000 & - & 0.482 & - & 0.000 & - & $0.010^{*}$ & -0.03 & 0.29 & 0.108 \\
\hline 37 & 0.882 & - & 0.000 & - & 0.820 & - & 0.000 & - & $0.000^{*}$ & -0.07 & 0.67 & 0.441 \\
\hline 39 & 0.772 & - & 0.000 & - & 0.503 & - & 0.000 & - & $0.039 *$ & -0.03 & 0.28 & 0.197 \\
\hline 43 & $0.025^{*}$ & 0.006 & 0.250 & 0.039 & $0.030^{*}$ & -0.00 & 0.276 & 0.06 & $0.000^{*}$ & -0.06 & 0.57 & 0.348 \\
\hline 44 & 0.086 & - & 0.000 & - & 0.939 & - & 0.000 & - & $0.000^{*}$ & -0.08 & 0.73 & 0.524 \\
\hline 47 & 0.324 & - & 0.000 & - & 0.075 & - & 0.000 & - & $0.001^{*}$ & -0.06 & 0.52 & 0.178 \\
\hline 48 & 0.450 & - & 0.000 & - & 0.649 & - & 0.000 & - & $0.000^{*}$ & -0.05 & 0.47 & 0.515 \\
\hline 51 & 0.511 & - & 0.000 & - & 0.999 & - & 0.000 & - & $0.000^{*}$ & -0.06 & 0.54 & 0.487 \\
\hline 52 & 0.642 & - & 0.000 & - & 0.667 & - & 0.000 & - & - & - & 0.00 & - \\
\hline 53 & $0.000^{*}$ & 0.021 & 0.875 & 0.439 & $0.000^{*}$ & -0.01 & 0.621 & 0.28 & $0.000^{*}$ & -0.05 & 0.45 & 0.343 \\
\hline 54 & 0.197 & - & 0.000 & - & $0.029^{*}$ & -0.01 & 0.621 & 0.43 & $0.014^{*}$ & -0.03 & 0.30 & 0.143 \\
\hline 57 & 0.387 & - & 0.000 & - & 0.594 & - & 0.000 & - & 0.004* & -0.05 & 0.49 & 0.407 \\
\hline 58 & 0.316 & - & 0.000 & - & 0.410 & - & 0.000 & - & $0.000^{*}$ & -0.05 & 0.50 & 0.365 \\
\hline 63 & 0.376 & - & 0.000 & - & $0.006^{*}$ & -0.02 & 0.897 & 0.33 & $0.013^{*}$ & -0.03 & 0.32 & 0.134 \\
\hline 64 & 0.140 & - & 0.000 & - & - & - & 0.000 & - & $0.000^{*}$ & -0.06 & 0.56 & 0.502 \\
\hline 73 & 0.500 & - & 0.000 & - & 0.941 & - & 0.000 & - & 0.964 & - & 0.00 & - \\
\hline 74 & - & - & 0.000 & - & - & - & 0.000 & - & 0.194 & - & 0.00 & - \\
\hline 77 & 0.204 & - & 0.000 & - & 0.654 & - & 0.000 & - & 0.719 & - & 0.00 & - \\
\hline 81 & 0.521 & - & 0.000 & - & 0.961 & - & 0.000 & - & $0.000^{*}$ & -0.04 & 0.39 & 0.192 \\
\hline 82 & 0.943 & - & 0.000 & - & 0.172 & - & 0.000 & - & 0.162 & - & 0.00 & - \\
\hline 83 & $0.001^{*}$ & 0.007 & 0.292 & 0.062 & $0.004 *$ & -0.00 & 0.310 & 0.05 & $0.000^{*}$ & -0.02 & 0.25 & 0.093 \\
\hline 84 & 0.110 & - & 0.000 & - & 0.696 & - & 0.000 & - & $0.000^{*}$ & -0.04 & 0.35 & 0.207 \\
\hline 87 & 0.727 & - & 0.000 & - & 0.474 & - & 0.000 & - & $0.000^{*}$ & -0.03 & 0.33 & 0.180 \\
\hline 91 & $0.045^{*}$ & 0.020 & 0.833 & 0.113 & 0.197 & - & 0.000 & - & 0.840 & - & 0.00 & - \\
\hline 92 & 0.448 & - & 0.000 & - & 0.109 & - & 0.000 & - & 0.937 & - & 0.00 & - \\
\hline 93 & 0.980 & - & 0.000 & - & 0.101 & - & 0.00 & - & 0.373 & - & 0.00 & - \\
\hline 97 & 0.287 & - & 0.000 & - & - & - & 0.000 & - & 0.512 & - & 0.00 & - \\
\hline $\begin{array}{l}{ }^{*} \mathrm{p} \text {-value } \\
\beta_{\mathrm{s}} \text { standar } \\
\text { - Not en }\end{array}$ & ized Beta & able & & & & & & & & & & \\
\hline
\end{tabular}


Table A.2. Statistical parameters from Panel Regression considering bean production

\begin{tabular}{|c|c|c|c|c|c|c|c|c|c|c|c|c|}
\hline \multicolumn{13}{|c|}{ Statistical parameters for bean } \\
\hline \multirow{2}{*}{$\begin{array}{c}\text { Sub } \\
\text { Region }\end{array}$} & \multicolumn{4}{|c|}{$1^{\text {st }}$ Perspective } & \multicolumn{4}{|c|}{$2^{\text {nd }}$ Perspective } & \multicolumn{4}{|c|}{$3^{\text {rd }}$ Perspective } \\
\hline & p-value & $\beta$ & $\beta_{\mathrm{s}}$ & $\mathrm{r}^{2}$ & p-value & $\beta$ & $\beta \mathrm{s}$ & $\mathrm{r}^{2}$ & $\mathrm{p}$-value & $\beta$ & $\beta \mathrm{s}$ & $\mathrm{r}^{2}$ \\
\hline 13 & $0.000 *$ & 0.012 & 0.750 & 0.1 & $0.000 *$ & -0.01 & 0.57 & 0.1 & $0.000^{*}$ & -0.04 & 0.60 & 0.4 \\
\hline 14 & 0.488 & - & 0.000 & - & 0.186 & - & 0.00 & - & $0.000^{*}$ & -0.04 & 0.60 & 0.3 \\
\hline 17 & 0.507 & - & 0.000 & - & 0.513 & - & 0.00 & - & 0.666 & - & 0.00 & - \\
\hline 21 & 0.970 & - & 0.000 & - & 0.820 & - & 0.00 & - & 0.556 & - & 0.00 & - \\
\hline 22 & 0.891 & - & 0.000 & - & 0.469 & - & 0.00 & - & $0.021 *$ & -0.01 & 0.15 & 0.2 \\
\hline 23 & $0.000 *$ & 0.016 & 1.000 & 0.3 & $0.000^{*}$ & -0.01 & 0.53 & 0.2 & $0.000^{*}$ & -0.01 & 0.19 & 0.1 \\
\hline 24 & $0.000 *$ & 0.014 & 0.875 & 0.5 & $0.006^{*}$ & -0.01 & 0.42 & 0.3 & $0.018^{*}$ & -0.01 & 0.15 & 0.1 \\
\hline 25 & - & - & 0.000 & - & - & - & 0.00 & - & 0.852 & - & 0.00 & - \\
\hline 27 & 0.739 & - & 0.000 & - & 0.400 & - & 0.00 & - & 0.970 & - & 0.00 & - \\
\hline 28 & - & - & 0.000 & - & - & - & 0.00 & - & 0.068 & - & 0.00 & - \\
\hline 31 & 0.123 & - & 0.000 & - & 0.898 & - & 0.00 & - & 0.102 & - & 0.00 & - \\
\hline 32 & - & - & 0.000 & - & - & - & 0.00 & - & - & - & 0.00 & - \\
\hline 33 & 0.840 & - & 0.000 & - & 0.899 & - & 0.00 & - & - & - & 0.00 & - \\
\hline 34 & $0.002 *$ & 0.011 & 0.688 & 0.4 & $0.007 *$ & -0.01 & 0.46 & 0.3 & - & - & 0.00 & - \\
\hline 37 & 0.428 & - & 0.000 & - & 0.200 & - & 0.00 & - & $0.002^{*}$ & -0.04 & 0.62 & 0.2 \\
\hline 39 & 0.540 & - & 0.000 & - & 0.225 & - & 0.00 & - & $0.032^{*}$ & -0.03 & 0.39 & 0.2 \\
\hline 43 & $0.015^{*}$ & 0.005 & 0.313 & 0.0 & 0.075 & - & 0.00 & - & $0.000^{*}$ & -0.05 & 0.71 & 0.3 \\
\hline 44 & 0.506 & - & 0.000 & - & 0.734 & - & 0.00 & - & $0.000^{*}$ & -0.07 & 1.00 & 0.5 \\
\hline 47 & 0.948 & - & 0.000 & - & 0.677 & - & 0.00 & - & $0.009^{*}$ & -0.04 & 0.53 & 0.1 \\
\hline 48 & 0.258 & - & 0.000 & - & 0.816 & - & 0.00 & - & $0.000^{*}$ & \begin{tabular}{|l|}
-0.04 \\
\end{tabular} & 0.56 & 0.4 \\
\hline 51 & 0.542 & - & 0.000 & - & 0.957 & - & 0.00 & - & 0.216 & - & 0.00 & - \\
\hline 52 & 0.219 & - & 0.000 & - & 0.284 & - & 0.00 & - & - & - & 0.00 & - \\
\hline 53 & $0.000 *$ & 0.013 & 0.813 & 0.3 & $0.000^{*}$ & -0.01 & 0.46 & 0.2 & $0.000^{*}$ & -0.04 & 0.50 & 0.2 \\
\hline 54 & 0.777 & - & 0.000 & - & $0.018^{*}$ & -0.01 & 0.53 & 0.4 & 0.089 & - & 0.00 & - \\
\hline 57 & 0.790 & - & 0.000 & - & 0.694 & - & 0.00 & - & 0.120 & - & 0.00 & - \\
\hline 58 & 0.255 & - & 0.000 & - & 0.518 & - & 0.00 & - & $0.001^{*}$ & -0.04 & 0.55 & 0.3 \\
\hline 63 & $0.011^{*}$ & 0.015 & 0.938 & 0.2 & 0.004* & -0.02 & 0.80 & 0.3 & 0.078 & - & 0.00 & - \\
\hline 64 & 0.191 & - & 0.000 & - & 0.127 & - & 0.00 & - & $0.000^{*}$ & -0.04 & 0.52 & 0.3 \\
\hline 73 & 0.157 & - & 0.000 & - & 0.101 & - & 0.00 & - & 0.115 & - & 0.00 & - \\
\hline 74 & - & - & 0.000 & - & - & - & 0.00 & - & 0.125 & - & 0.00 & - \\
\hline 77 & 0.437 & - & 0.000 & - & 0.067 & - & 0.00 & - & 0.507 & - & 0.00 & - \\
\hline 81 & 0.648 & - & 0.000 & - & 0.938 & - & 0.00 & - & $0.000^{*}$ & -0.03 & 0.38 & 0.1 \\
\hline 82 & 0.257 & - & 0.000 & - & - & - & - & - & - & - & 0.00 & - \\
\hline 83 & $0.000 *$ & 0.005 & 0.313 & 0.0 & $0.016^{*}$ & -0.01 & 0.27 & 0.0 & $0.000^{*}$ & -0.02 & 0.28 & 0.0 \\
\hline 84 & $0.000^{*}$ & 0.016 & 1.000 & 0.5 & $0.030 *$ & -0.03 & 1.00 & 0.3 & $0.000^{*}$ & \begin{tabular}{|l|}
-0.03 \\
\end{tabular} & 0.39 & 0.1 \\
\hline 87 & $0.034^{*}$ & 0.006 & 0.375 & 0.2 & 0.186 & - & 0.00 & - & $0.000^{*}$ & -0.02 & 0.34 & 0.1 \\
\hline 91 & 0.637 & - & 0.000 & - & 0.569 & - & 0.00 & - & 0.694 & - & 0.00 & - \\
\hline 92 & 0.879 & - & 0.000 & - & 0.166 & - & 0.00 & - & 0.767 & - & 0.00 & - \\
\hline 93 & 0.819 & - & 0.000 & - & 0.639 & - & 0.00 & - & 0.278 & - & 0.00 & - \\
\hline 97 & - & - & 0.000 & - & - & - & 0.00 & - & 0.264 & - & 0.00 & - \\
\hline \multicolumn{13}{|c|}{${ }^{*}$ p-value $<0.05$} \\
\hline \multicolumn{13}{|c|}{$\beta_{\mathrm{s}}$ standardized Beta } \\
\hline & & & & & & & & & & & & \\
\hline
\end{tabular}




\section{Appendix B:}

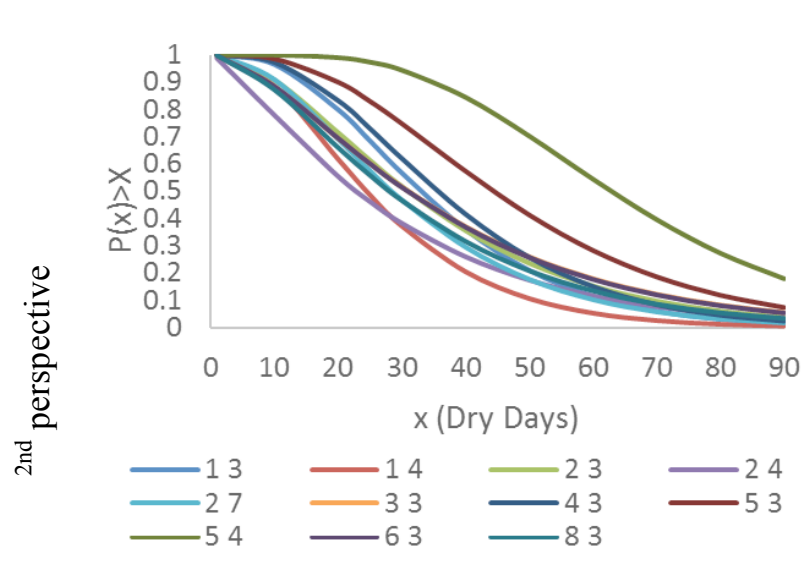

\begin{tabular}{ccc}
\hline Sub-region & $\mathbf{P}(\mathbf{x}>\mathbf{2 0})$ & $\begin{array}{c}\text { Minimum } \\
\text { Crop } \\
\text { (Kg/ha) }\end{array}$ \\
\hline $\mathbf{1 3}$ & $80 \%$ & 125.1 \\
$\mathbf{1 4}$ & $62 \%$ & 130.6 \\
$\mathbf{2 3}$ & $72 \%$ & 162.9 \\
$\mathbf{2 4}$ & $55 \%$ & 136.9 \\
$\mathbf{2 7}$ & $69 \%$ & 205.4 \\
$\mathbf{3 3}$ & $69 \%$ & 199.5 \\
$\mathbf{4 3}$ & $83 \%$ & 119.2 \\
$\mathbf{5 3}$ & $90 \%$ & 193.8 \\
$\mathbf{5 4}$ & $99 \%$ & 558.4 \\
$\mathbf{6 3}$ & $69 \%$ & 255.7 \\
$\mathbf{8 3}$ & $66 \%$ & 171.1 \\
\hline
\end{tabular}

Figure B.1. Risk analysis for maize. 


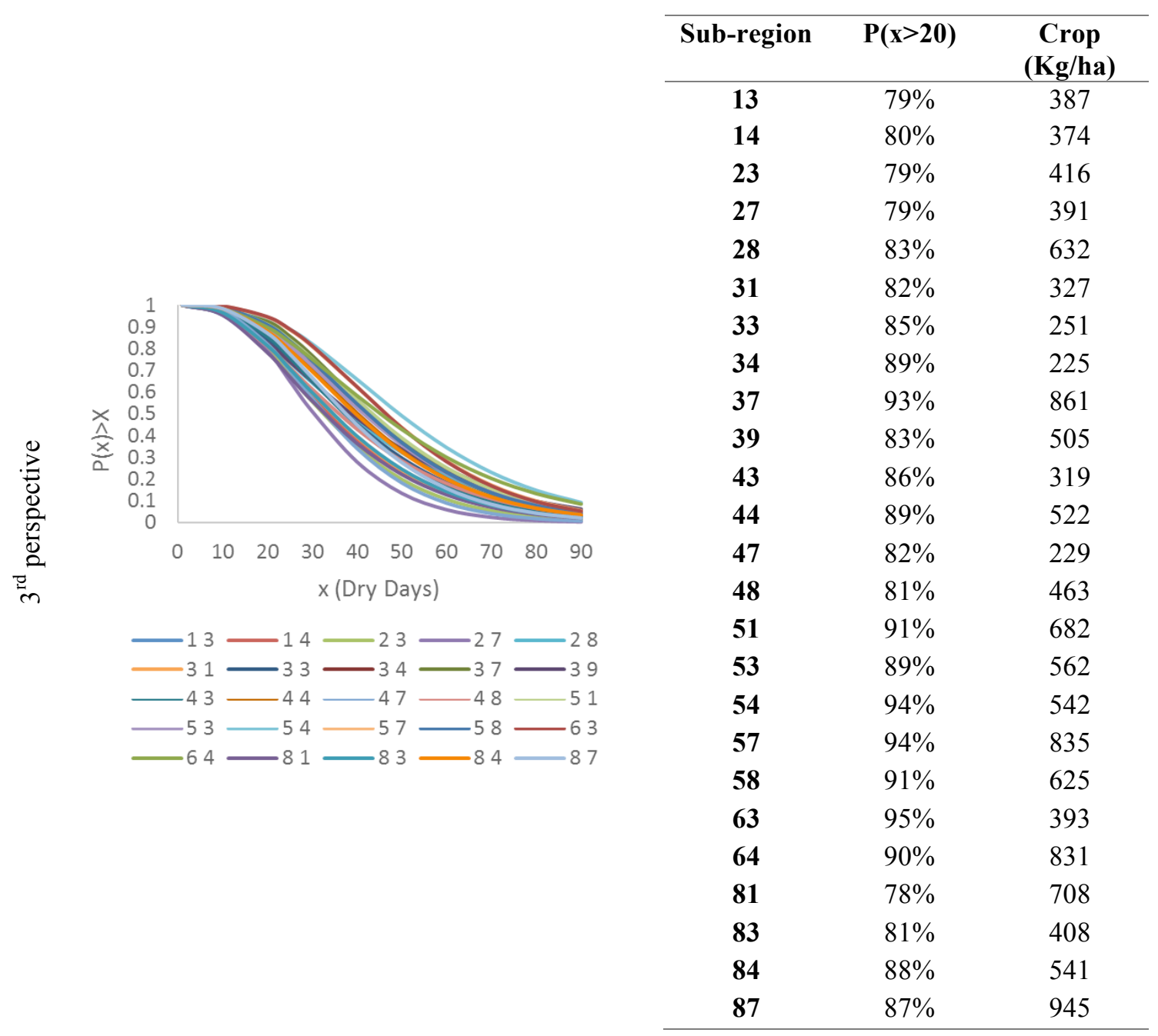

Figure B.2. Risk analysis for maize. 
Appendix C: Risk Analysis for Bean

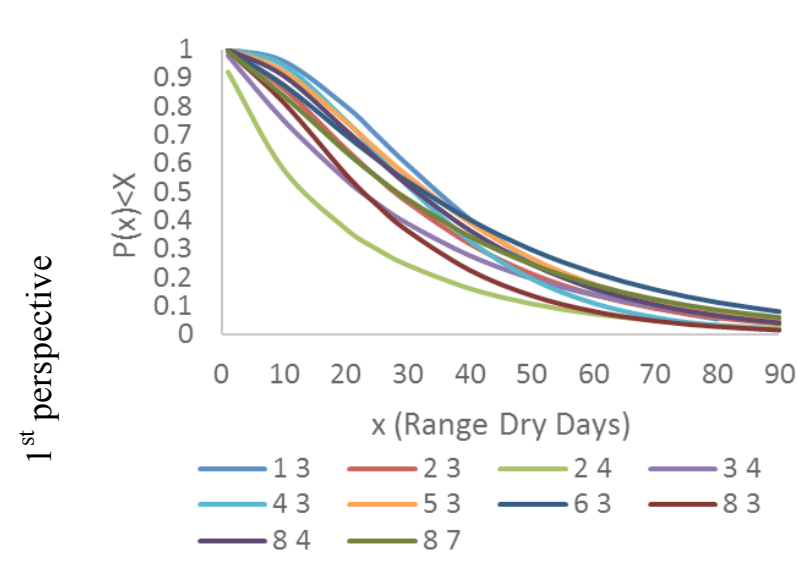

\begin{tabular}{ccc}
\hline Sub-region & $\mathrm{P}(\mathrm{x}>20)$ & Crop Loss \\
\hline $\mathbf{1 3}$ & $80 \%$ & $86.0 \%$ \\
$\mathbf{2 3}$ & $65 \%$ & $80.6 \%$ \\
$\mathbf{2 4}$ & $37 \%$ & $77.9 \%$ \\
$\mathbf{3 4}$ & $54 \%$ & $75.3 \%$ \\
$\mathbf{4 3}$ & $75 \%$ & $86.7 \%$ \\
$\mathbf{5 3}$ & $75 \%$ & $76.3 \%$ \\
$\mathbf{6 3}$ & $70 \%$ & $69.3 \%$ \\
$\mathbf{8 3}$ & $56 \%$ & $79.9 \%$ \\
$\mathbf{8 4}$ & $72 \%$ & $87.6 \%$ \\
$\mathbf{8 7}$ & $64 \%$ & $80.6 \%$ \\
\hline
\end{tabular}

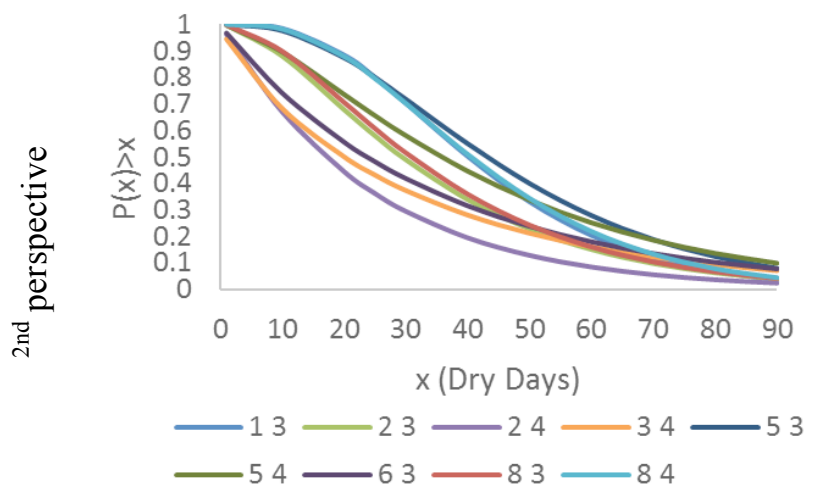

\begin{tabular}{ccc}
\hline Sub-region & $\mathrm{P}(\mathrm{x}>20)$ & $\begin{array}{c}\text { Minimum } \\
\text { Crop }(\mathrm{Kg} / \mathrm{ha})\end{array}$ \\
\hline $\mathbf{1 3}$ & $89 \%$ & 66.4 \\
$\mathbf{2 3}$ & $68 \%$ & 67.5 \\
$\mathbf{2 4}$ & $45 \%$ & 71.8 \\
$\mathbf{3 4}$ & $50 \%$ & 190.4 \\
$\mathbf{5 3}$ & $87 \%$ & 153.5 \\
$\mathbf{5 4}$ & $74 \%$ & 345.2 \\
$\mathbf{6 3}$ & $56 \%$ & 197.7 \\
$\mathbf{8 3}$ & $71 \%$ & 162.7 \\
$\mathbf{8 4}$ & $88 \%$ & 192.3 \\
\hline
\end{tabular}

Figure C.1. Risk analysis for bean 


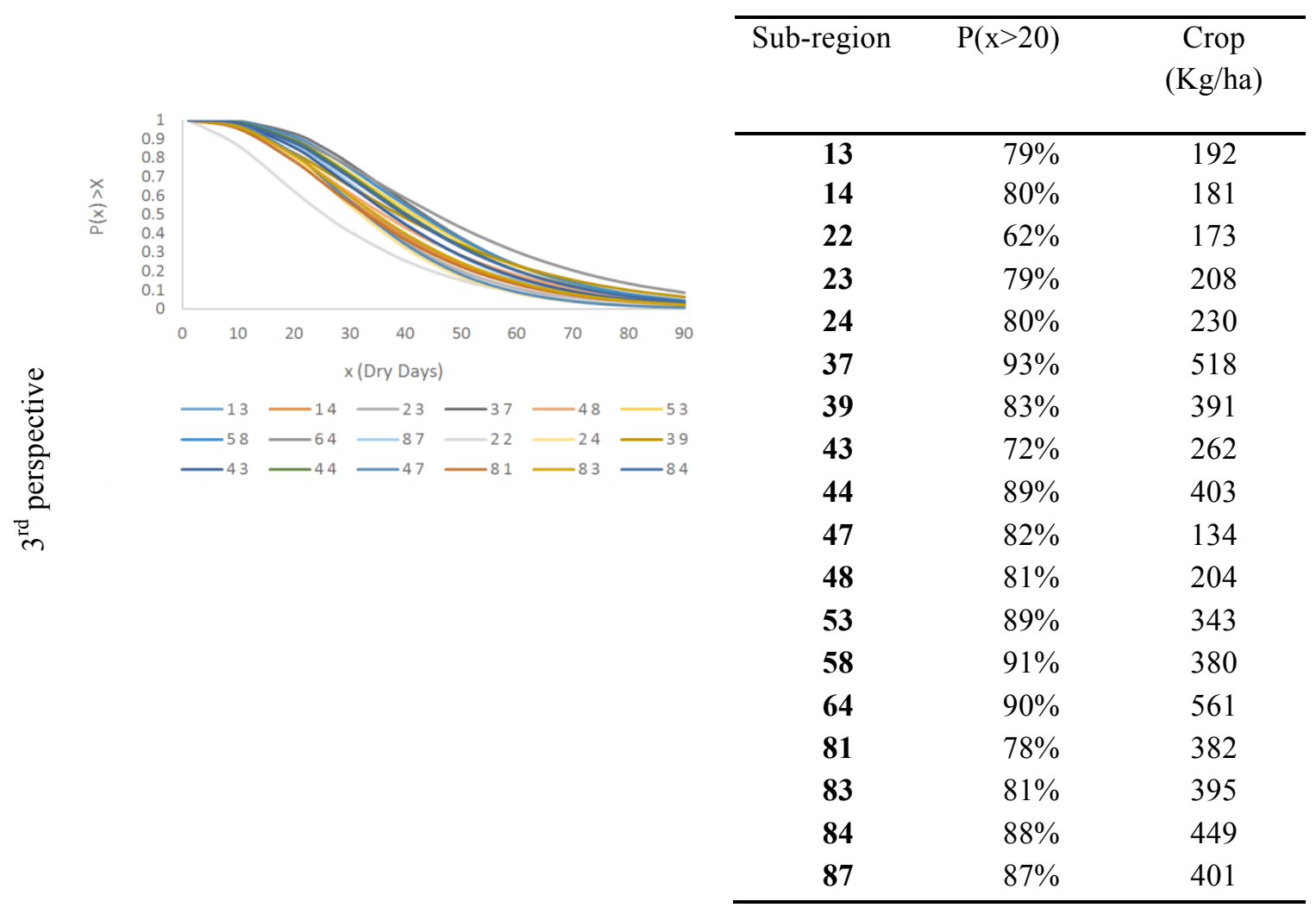

Figure C.2. Risk analysis for bean. 